\title{
Bilateral eruption cysts associated with primary molars in both the jaws
}

\author{
Chandan D Gaddehosur, ${ }^{1}$ Suma Gopal, ${ }^{1}$ Prashanth T Seelinere, ${ }^{1}$ \\ Basavaraj S Nimbeni
}

${ }^{1}$ Pedodontics and Preventive Dentistry, V S Dental College and Hospital, Bangalore, Karnataka, India

${ }^{2}$ Pedodontics and Preventive Dentistry, A M E's Dental College Hospital \& Research Centre, Raichur, Karnataka, India

Correspondence to Dr Basavaraj S Nimbeni, drbassu@gmail.com

Accepted 4 April 2014

\section{SUMMARY}

Disturbances of tooth development may result in anomalies which appear in the form of swelling of the overlying mucosa of the erupting deciduous or permanent teeth, mostly in children. Eruption cyst (EC), a benign cyst is one such lesion associated with erupting teeth. ECs usually present as solitary swellings on the alveolar ridge mucosa, whereas multiple ECs presenting simultaneously or in short intervals are unusual. Here, we present a rare case of four large bilateral ECs presenting with swellings and pain in the posterior region of each quadrant in the mouth. The treatment included surgical excision under general anaesthesia and exposure of the unerupted primary teeth.

\section{BACKGROUND}

Eruption cyst (EC) is a benign lesion associated with an erupting tooth. It occurs in the mucosa overlying the teeth that is about to erupt and according to the current WHO classification of epithelial cysts of the jaws, EC is a separate entity. ${ }^{1}$ Clinically, EC appears as a dome-shaped raised swelling in the mucosa of the alveolar ridge which is soft to touch and the colour ranges from transparent, bluish, purple to blue-black. ECs generally involve part of, or whole of an unerupted crown area including the lingual area. The size depends on whether it is associated with primary tooth or permanent tooth and the number of teeth involved. They generally measure $1 \times 1 \mathrm{~cm}$ in diameter and can be present bilaterally or unilaterally. ${ }^{2}$ Majority of ECs disappear on their own and usually do not require any treatment. If they hurt, bleed or are infected they may require surgical treatment to expose the tooth and drain the contents. ${ }^{13}$

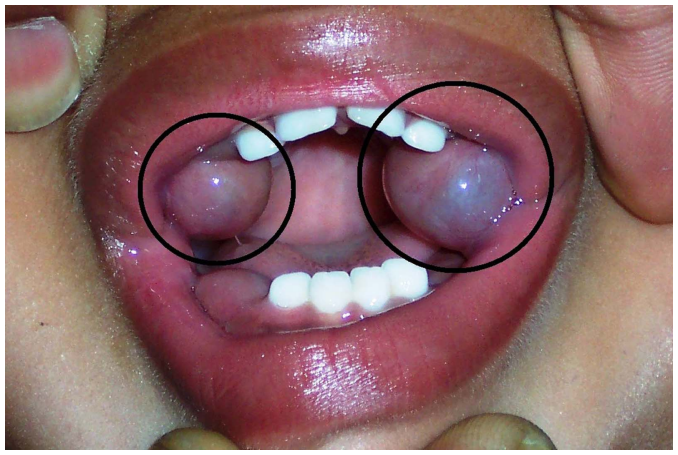

Figure 1 Bilateral eruption cysts-maxillary molars.

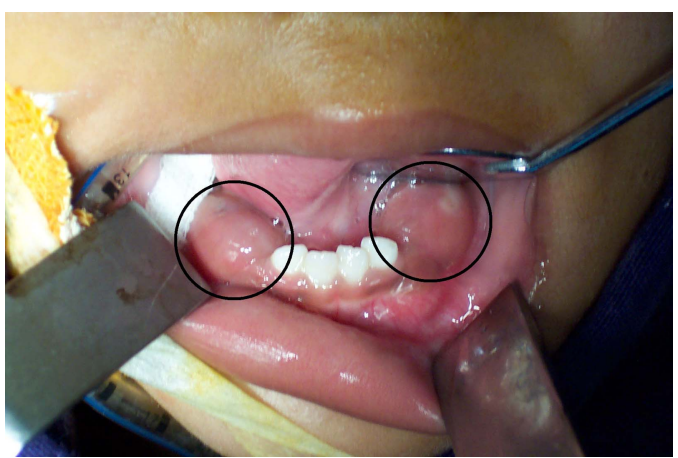

Figure 2 Bilateral eruption cysts-mandibular molars.

\section{CASE PRESENTATION}

We hereby report a case of multiple ECs in a 22-month-old male child who reported to our outpatient department with symptoms of swelling, pain and unable to eat since 2 weeks. History of the presenting illness revealed that the swellings developed 2 weeks ago and gradually increased in size with occasional reduction in their size and would increase again. The child avoided eating and was irritable.

On general examination, it was seen that the child was moderately built, moderately nourished with normal motor coordination. Body temperature of the child was raised $\left(99^{\circ} \mathrm{F}\right)$ and he showed uncooperative behaviour. The child weighed $13 \mathrm{~kg}$ when admitted to the hospital. Intraoral examination revealed that the patient had eight primary teeth, that is, the maxillary central and lateral incisors and mandibular central and lateral incisors. Two swellings were present in the upper and lower right and left molar regions (figures 1 and 2). The colour of the swellings varied between reddish pink

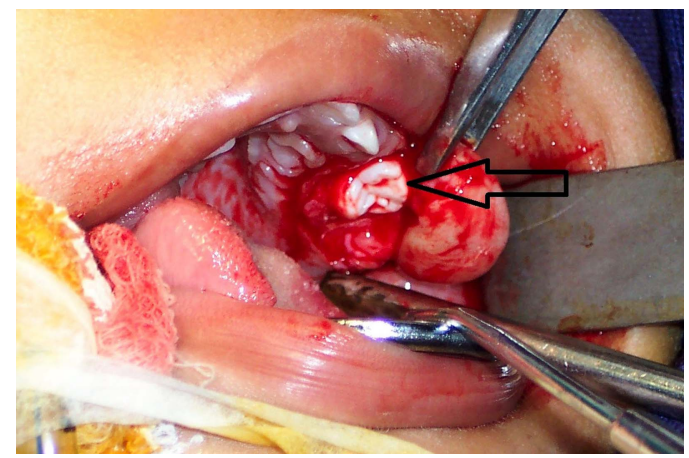

Figure 3 Surgical excision of eruption cyst in the upper left quadrant. 


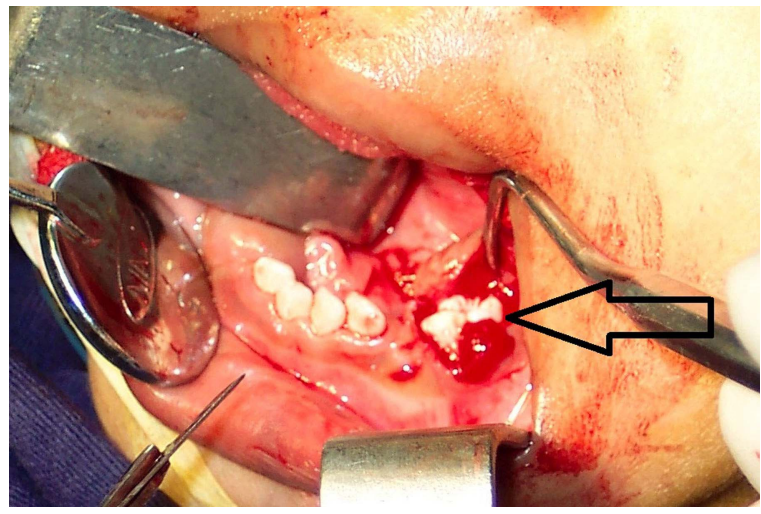

Figure 4 Surgical excision of eruption cyst in the lower left quadrant.

to purple. The swellings measured $2 \mathrm{~cm} \times 2 \mathrm{~cm}$ in size and were tender and fluctuant on palpation. Based on the clinical findings provisional diagnosis of multiple ECs was made. The case was planned to be diagnosed and treated under general anaesthesia due to the age and uncooperative nature of the patient. Fine-needle aspiration cytology was performed which showed the presence of a straw-coloured fluid containing inflammatory cells. Surgical exposure was carried out and the teeth were exposed. The cyst wall was excised and was sent for histopathological examination (figures 3-7). Histopathological examination of the specimen showed surface oral epithelium on the superior aspect, the underlying lamina propria showed variable inflammatory cell infiltrate. The deep portion of the specimen which represents the roof of the cyst showed thin layer of nonkeratinised squamous epithelium. Thus diagnosis of EC was confirmed (figure 8).

\section{INVESTIGATIONS}

- Fine-needle aspiration cytology

- Excisional biopsy

\section{DIFFERENTIAL DIAGNOSIS}

- The differential diagnosis includes

- EC

- Haemangioma

- Melanotic neuroectodermal tumour of infancy

- Congenital epulis

- Neonatal alveolar lymphangioma

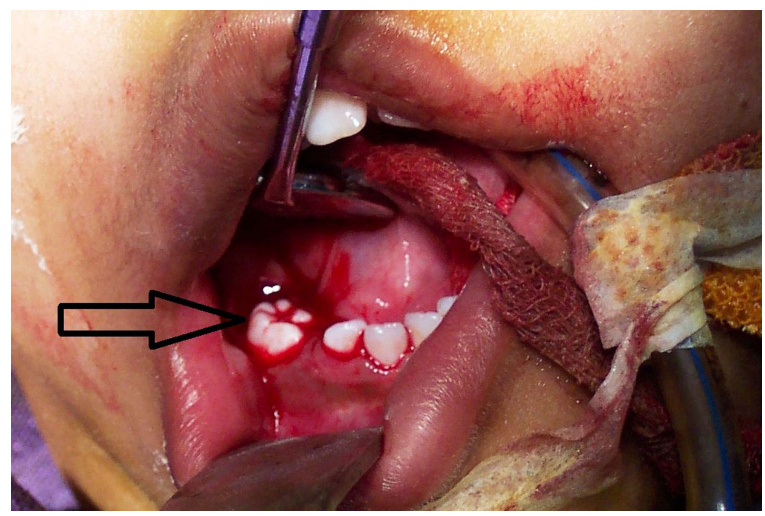

Figure 5 Surgical excision of eruption cyst in the lower right quadrant.

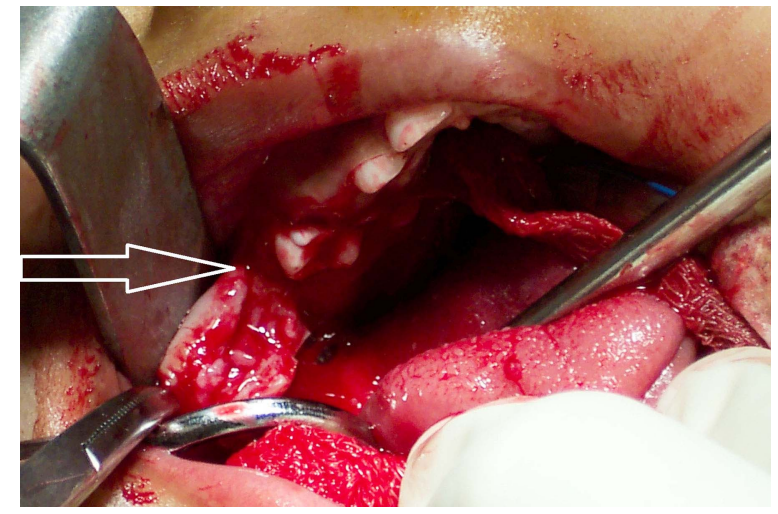

Figure 6 Surgical excision of eruption cyst in the upper right quadrant.

\section{TREATMENT}

Surgical exposure of the teeth covered by the cystic lining was performed under general anaesthesia.

\section{OUTCOME AND FOLLOW-UP}

Patient was under follow-up for 4 months and normal eruption of primary molars involved in cyst formation was clinically seen.

\section{DISCUSSION}

Occurrence of congenital cysts in the oral cavity is rare and they present a great challenge for paediatricians, paediatric surgeons, paediatric dentists and oral and maxillofacial surgeons. There are various causes of intraoral cystic lesions which include enteric duplication cysts, dermoid and epidermoid cyst, haemangioma, ranula, mucocele, lingual thyroid, lymphoepithelial cyst, cystic hygroma, ECs and Bohn's nodule. ${ }^{1}$ Complications associated with congenital pathologies in the oral cavity include pain on sucking, refusal to feed, irritability, respiratory difficulty because of airway obstruction, aspiration of fluids or teeth when natal or neonatal teeth are present. ${ }^{4}$

The EC occurs when a tooth is impeded in its eruption within the soft tissues overlying the bone. The exact aetiology of occurrence of EC is not clear. Although there are a number of theories about their origin they seem to arise from the separation of the epithelium from the enamel of the crown of the tooth due to accumulation of fluid or blood in a dilated follicular space. ${ }^{4}$ The effect of certain drugs like ciclosporin on tooth eruption and in the pathogenesis of ECs is a matter of

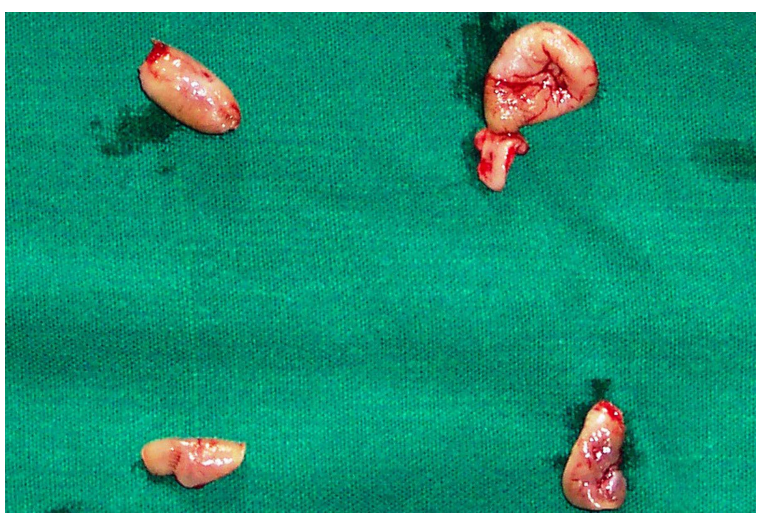

Figure 7 Excised epithelial cyst. 


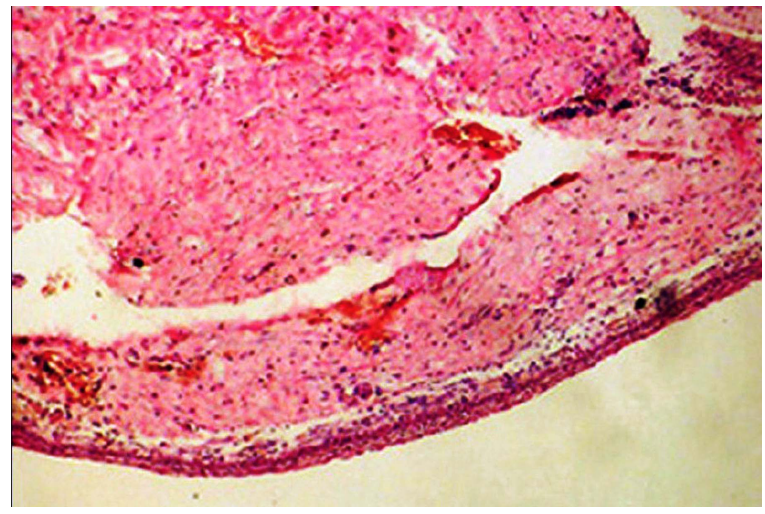

Figure 8 Histopathology of cystic lining showing inflammatory cell infiltration in the epithelium.

controversy. In children, CyA administration at the time of tooth eruption may result in EC formation, thus resisting tooth eruption. ${ }^{5}$ The literature shows small number of reported cases of ECs and they appear to be more prevalent in the Caucasian race. ${ }^{6}$ The clinical impression of low prevalence may also be due to the fact that most often the dentist sees only symptomatic ECs and the majority resolve by themselves. Anderson reported 54 cases over 16 years, which were histologically confirmed. Aguilo et al reported 36 cases in their retrospective study of 15 years. Later, Bodner found a prevalence of ECs of 22\% among various maxillary cystic lesions in 69 children. Recently, in 2004 Bodner et al once again presented 24 new cases of ECs. ${ }^{8-11}$ EC and haematoma are usually found to be present in the first and second decades of life.

Clinically, EC appears as a soft translucent swelling, most commonly associated with the deciduous mandibular central incisors, first permanent molars and deciduous maxillary

\section{Table 1}

\begin{tabular}{|c|c|c|c|c|c|c|}
\hline Authors & Sex & Race & Age & Site & Jaw & \\
\hline $\begin{array}{l}\text { Peters and } \\
\text { Schock }(1971)^{13}\end{array}$ & $\mathrm{~F}$ & B & Newborn & $\mathrm{Cl}$ & $\mathrm{L}$ & $\begin{array}{l}\text { Bilateral and } \\
\text { symmetrical }\end{array}$ \\
\hline $\begin{array}{l}\text { Nomura et al }{ }^{14} \\
\text { (1996) }\end{array}$ & $\mathrm{M}$ & $A$ & 4 & $\mathrm{Cl}-\mathrm{M}$ & U & $\begin{array}{l}\text { Bilateral and } \\
\text { symmetrical, } \\
\text { kinky-hair disease }\end{array}$ \\
\hline Aguilo et $a l^{9}$ & $\begin{array}{l}\mathrm{M} \\
\mathrm{F} \\
\mathrm{M} \\
\mathrm{F} \\
\mathrm{F} \\
\mathrm{M}\end{array}$ & $\begin{array}{l}n / s \\
n / s \\
n / s \\
n / s \\
n / s \\
n / s\end{array}$ & $\begin{array}{l}6.2 \\
6.11 \\
6.11 \\
6.9 \\
6.11 \\
8.8\end{array}$ & $\begin{array}{l}\mathrm{M} \\
\mathrm{M} \\
\mathrm{M} \\
\mathrm{Cl}-\mathrm{M} \\
\mathrm{LI} \\
\mathrm{Cl}-\mathrm{LI}\end{array}$ & $\begin{array}{l}U / L \\
U \\
U / L \\
U \\
U \\
U\end{array}$ & $\begin{array}{l}\text { Bilateral and } \\
\text { symmetrical } \\
\text { Bilateral and } \\
\text { symmetrical } \\
\text { Bilateral and } \\
\text { symmetrical }\end{array}$ \\
\hline $\begin{array}{l}\text { Boj and } \\
\text { Garcia-Godoy } \\
(2000)^{15}\end{array}$ & $\mathrm{M}$ & $\mathrm{n} / \mathrm{s}$ & 1.3 & $\mathrm{Cl}-\mathrm{M} / \mathrm{M}$ & $\mathrm{U} / \mathrm{L}$ & Homolateral \\
\hline Ricci et al (2008) & $\mathrm{M}$ & B & Newborn & $\mathrm{Cl}$ & $\mathrm{L}$ & $\begin{array}{l}\text { Bilateral and } \\
\text { symmetrical }\end{array}$ \\
\hline $\begin{array}{l}\text { Karp and Milner } \\
(2009)^{16}\end{array}$ & M & $\mathrm{C}$ & 1 & $\mathrm{M}$ & $\mathrm{U} / \mathrm{L}$ & Homolateral \\
\hline Zarakas et al ${ }^{12}$ & $\mathrm{M}$ & $\mathrm{C}$ & 2 months & $\mathrm{Cl}$ & $\mathrm{L}$ & $\begin{array}{l}\text { Bilateral and } \\
\text { symmetrical }\end{array}$ \\
\hline Present case & $\mathrm{M}$ & A & 22 months & $\begin{array}{l}M / M \\
M / M\end{array}$ & $\begin{array}{l}U / L \\
U / L\end{array}$ & $\begin{array}{l}\text { Bilateral and } \\
\text { symmetrical }\end{array}$ \\
\hline
\end{tabular}

incisors. They generally measure $1 \times 1 \mathrm{~cm}$ in diameter and can be present bilaterally or unilaterally. ${ }^{3}{ }^{9}$ However in our case four ECs were found associated with four deciduous molars in all the four quadrants and the swellings varied between reddish pink to purple measuring $2 \mathrm{~cm} \times 2 \mathrm{~cm}$ in size and were tender and fluctuant on palpation.

Since the patient was uncooperative, treatment was planned under general anaesthesia. Fine-needle aspiration cytology showed the presence of a straw-coloured fluid containing inflammatory cells. The cystic epithelium was excised and sent for histopathology. In the histopathology section, it was seen that the surface oral epithelium was present on the superior aspect, the underlying lamina propria showed variable inflammatory cell infiltrate. The deep portion of the specimen represented the roof of the cyst which showed a thin layer of non-keratinising squamous epithelium. Thus the diagnosis of ECs was confirmed.

ECs if small do not require treatment and the affected tooth erupts normally. ${ }^{5}$ In the present case, treatment was necessary as the patient was unable to eat and speak because of large size of cysts. Surgical exposure of the teeth covered by the cysts was performed under general anaesthesia and the patient was under observation for 4 months and normal eruption of molars was clinically seen.

The literature shows very few cases of multiple ECs being reported. Table 1 shows some important clinical features of 13 cases of multiple ECs as observed by various authors. ${ }^{12}$

EC is a clinically asymptomatic isolated lesion associated with an unerupted tooth (primary and permanent) but when it is large and gets secondarily infected it causes pain, discomfort and difficulty in mastication which makes treatment of such cases necessary. Clinician's knowledge and skill is very necessary for correct diagnosis and treatment of these cases.

\section{Learning points}

- Eruption cyst is a benign lesion associated with an erupting tooth which is developmental in origin.

- They appear reddish pink to purple in colour and are present on the alveolar mucosa overlying an unerupted tooth.

- There are no obvious radiographic findings, fine-needle aspiration cytology and histopathological examination of the cystic lining are confirmatory.

- Treatment is based on the size of the lesion and includes surgical excision of the cystic lining in most of the cases.

Acknowledgements Dr Shruti Golai, Assistant Professor, Department of Pedodontics and Preventive Dentistry A M E's Dental College Hospital and Research Centre, Raichur contributed in the collection of data and in preparing the manuscript.

Contributors CDG was involved in conception and design. SG was involved in revising the manuscript critically for important intellectual content. PTS was involved in the acquisition of data. BSN was involved in the interpretation of data.

Competing interests None.

Patient consent Obtained.

Provenance and peer review Not commissioned; externally peer reviewed.

\section{REFERENCES}

1 Neville BW, Damm DD, Allen CM, et al. Odontogenic cysts and tumours. In: Damm DD, Bouquot JE, Neville BW, eds. Oral and maxillofacial pathology. 3rd edn. Pennsylvania: Saunders Elsevier, 2009:682-3. 
2 Regezi J, Sciubba J, Jordan R. Cysts of the oral region. In: Oral pathology: clinicalpathologic correlations. 5th edn. St. Louis, Mo: Saunders Elsevier, 2008:241-4.

3 Nagaveni NB, Umashankara KV, Radhika NB, et al. Eruption cyst: a literature review and four case reports. Indian J Dent Res 2011;22:148-51.

4 Stewart RE, Barber TK, Troutman KC. Pediatric dentistry, scientific foundations and clinical practice. ST. Louis: C.V. Mosby, 1982.

5 Kuczek A, Beikler T, Herbst $\mathrm{H}$, et al. Eruption cyst formation associated with cyclosporin A. A case report. J Clin Periodontol 2003;30:462-6.

6 Nunn JH. Eruption problems: a cautionary tale. J Dent Child 1993;60:207-10.

7 Shaul H, Chatra L, Shenai $P$, et al. Eruption cyst: a case report. Pac J Med Sci 2013;11:34-8

8 Anderson RA. Eruption cyst: a retrograde study. J Dent Child 1990;57:124-7.

9 Aguilo L, Cibrian R, Bagan JV, et al. Eruption cysts: retrospective clinical study of 36 cases. J Dent Child 1998:65:102-6.
10 Bodner L. Cystic lesions of the jaws in children. Int I Pediatr Otorhinolaryngol 2002;62:25-9.

11 Bodner L, Goldstein J, Sarnat H. Eruption cysts: a clinical report of 24 new cases. J Clin Pediatr Dent 2004;28:183-6.

12 Zarakas M, Tsinidou K, Triantafyllou C, et al. Double eruption cyst in a newborn boy. Case report and review of the literature. Hell Arch Oral Maxillofac Surg 2012;13:41-8.

13 Peters R, Schock R. Oral cysts in newborn infants. Oral Surg 1971;32:10-4.

14 Nomura J, Tagawa T, Seki Y, et al. Kinky hair disease with multiple eruption cysts. Oral Surg Oral Med Oral Pathol Oral Radiol Endo 1996;82:537-40.

15 Boj JR, Garcia-Godoy F. Multiple eruption cysts: report of case. ASDC J Dent Child 2000;67:282-4.

16 Karp JM, Milner LA. Oral eruption cysts in a child with hepatoblastoma. J Pediatr Hematol Oncol 2009:31:509-11.

Copyright 2014 BMJ Publishing Group. All rights reserved. For permission to reuse any of this content visit http://group.bmj.com/group/rights-licensing/permissions.

BMJ Case Report Fellows may re-use this article for personal use and teaching without any further permission.

Become a Fellow of BMJ Case Reports today and you can:

- Submit as many cases as you like

- Enjoy fast sympathetic peer review and rapid publication of accepted articles

- Access all the published articles

- Re-use any of the published material for personal use and teaching without further permission

For information on Institutional Fellowships contact consortiasales@bmjgroup.com

Visit casereports.bmj.com for more articles like this and to become a Fellow 